\title{
アユ養殖場における薬剤耐性菌増加について
}

\author{
青木 宙*・城 泰彦**. 江 草周三*** \\ (昭和 54 年 11 月 28 日受理)
}

\section{Frequent Occurrence of Drug Resistant Bacteria in Ayu (Plecoglossus altivelis) Culture}

\author{
Takashi Aokr*, Yasuhiko Jo** and Syuzo EguSA*** \\ *Dept. of Fish., Fac. of Agr., Miyazaki Univ., Miyazaki, Japan \\ **Fish. Exp. Stn. of Tokushima Pref. Tokushima, Japan \\ ***Dept. of Fish., Fac. of Agr., Univ. of Tokyo, Tokyo, Japan
}

(Received November 28, 1979)

\begin{abstract}
Chloramphenicol (CM)- and tetracycline (TC)-resistant bacteria which could grow on Heart Infusion agar containing $6.2 \mathrm{mcg} / \mathrm{m} l$ of $\mathrm{CM}$ or TC, respectively, were isolated with high frequencies from the intestinal tracts of cultured Ayu (Plecoglossus altivelis) and the water of Ayu culturing ponds in Tokushima Pref. CM- and TC-resistant bacteria were not isolated from the intestinal tracts of wild Ayu collected from the river Nakagawa in Tokushima Pref. The principal drug resistant bacteria isolated from the intestinal tracts were Aeromonas hydrophila and Vibrio anguillarum. Drug resistant Pseudomonas, Enterobacter aerogenes, E. cloacae, Escherichia coli, Hafnia, Salmonella arizonae and other unidentified Enterobacteriaceae were occasionally found. Drug resistant bacteria isolated from the water of ponds were common to those from the intestinal tracts. However, drug resistant E. coli, Psudomonas and V. anguillarum were not isolated from the water. All drug resistant $V$. anguillarum strains carried $\mathrm{R}$ plasmids. $\mathrm{R}$ plasmids were detected in a part of the Hafnia, E. cloacae, A. hydrophila, unidentified Enterobacteriaceae and E. aerogenes strains. The drug resistance markers present in the $\mathrm{R}$ plasmid bearing strains were in most cases sulfonamides streptomycin CM and TC.
\end{abstract}

1973 年以来, 海年全国各地のアコ養殖場でビブリオ病 が多発し，少なかな被羖を出している。その被害が大 きい要因の一つとして, 原因菌の Vibrio anguillarum が，養殖場で㕕く使用されているサルファ剂，クロラム フェニコール, テトラサイクリン, ニトロフラン誘導体 あるいはナリジキシック酸誘導体等の化学療法剤に対し 耐珄を有することが多く，治療を困難にしていることが 挙げられる。しかもそれら耐性は多くの場合伝達性薬郕

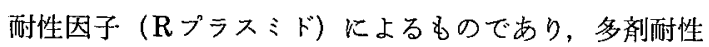
を示す (Aoki et al., 1974)。そして治療困難であること がかえって多種多用の化学療法剤の使用を促している。 このことから V. anguillarum のみならず養殖池水やア ユの腸管に生息する種々の細菌でも耐性株は増加してい るものと推察される。この推察を裏付けるために我々は

* 宮崎大学軖学部水産增殖学科

** 徳島県水産試験場

*** 東京大学農学部水産学科

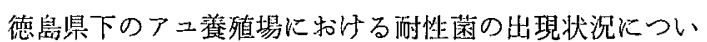
て調查を行なった。 本報告はその調查結果をまとめたものである。な拉， この結果の一部はさきの魚病研究談話会主催で行なわれ た「魚類の感染症の予防に関する」シンポジウムで公表 した（青木ら, 1978)。

\section{材料および方法}

1974 年 4 月, 徳島紧下の 14 の浪殖場の各 1 池より各 5 尾のアュを採集した。調查時点で 14 池のうち 11 池の アニにビブリオ病の発生が観察され, さらに別の 1 池の アニでは真菌性肉芽隀症が認められた。採集した魚はア イスボックスに収容し，その日のうちに実験室に持帰 り, 体長および体重を測定後, 腸管を無菌的に摘出し, 等量の隇菌生理食塩水を加えて $2,000 \mathrm{rpm}$ で，3 分間亦 モジナイズした。ホモジナイズしたものを 5 尾プール し, 隇菌生理食塩水で $10^{-1} \sim 10^{-3}$ まで 10 段階稀橎し 
た。各稀釈液の $0.1 \mathrm{~m} l$ chloramphenicol (三共) (CM) またはtetracycline (レダリー) (TC)を $6.2 \mathrm{mcg} /$ $\mathrm{m} l$ を念さハートインフュージョン $(\mathrm{HI})$ 寒天平板培地 （栄研）と，それらを含まない同じ培地上に塗抹・培湌 し, 定量的に菌数を求めた。また，14 池のうちの 4 池 (いずれもビブリオ病の発生が認められた)について, 池 水中の細菌を同様の方法で定量しだ。

一方，薬剂にまったく触れていないと思われる德島県 那賀川の野生アコを 5 尾, 1974 年 4 月に採捕し, 上記 の養殖アニと同様に処理して晹管の細菌数を定量した。

培養は $28^{\circ} \mathrm{C}$ で 48 時間行なった。池別に, 上記 3 種 類の $\mathrm{HI}$ 寒天平板培地に増殖した形態を異にする4（と きに3，または 8) コロニーを釣菌し，それぞれの分離 平板培地と同じ平板培地に再分離した。邽分離した菌は Bergey's Manual 第 8 版 (BuchnAN et al., 1974) およ び CowaN (1974) の分類に従って同定した。CM また は TC を含む平板培地に増殖可能であった菌について
は, 大腸菌 K-12 の Substrain である RC 85 nal (nalidixic acid 耐性) と混合培着し，RC 85 nal へ耐性 の伝達の有無を調べた。さらに，検出された伝達性 R プ ラスミドの耐性マーカーをディスク法を用いて求めた (AoKI et al., 1974)。

\section{結果}

\section{1) 耐性菌の出現頻度}

14 池の養殖アユ腸管 $1 \mathrm{~g}$ 当りの細菌数 (全細菌数) は $9.9 \times 10^{6} \sim 1.1 \times 10^{8}$ で，それらの平均は $3.3 \times 10^{7}$ で あった。同じ材料から CM $6.2 \mathrm{mcg} / \mathrm{ml}$ を含む HI 寒天 平板培地に増殖可能であった細菌（以下 CM 耐性菌と 呼ぶ）の全細菌数に対する比率（以下出現率と呼ぶ）は $33.3 \sim 100 \%$, 平均で $75.9 \%$ と非常に高く, 14 池のう ちの5池では $100 \%$ の値を示した (Table 1)。TC 6.2 $\mathrm{mcg} / \mathrm{m} l$ を含む $\mathrm{HI}$ 寒天平板培地に増殖可能であった細 菌（以下 TC 耐性菌之呼ぶ）の出現率は，4.2 100\%，

Table 1. Incidence of chloramphenicol- and tetracycline-resistant bacteria* in the intestinal tracts of Ayu (Plecoglossus altivelis)

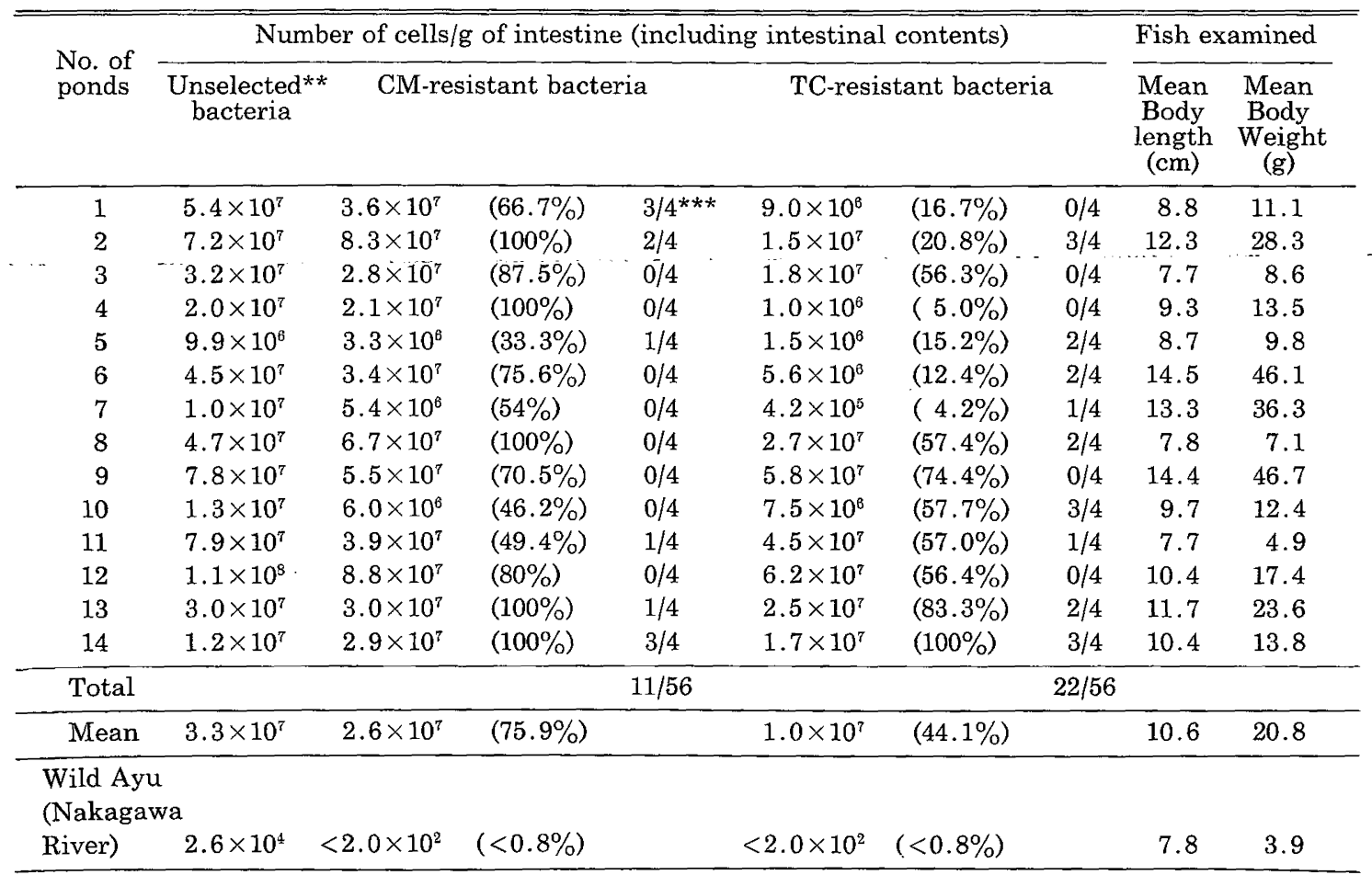

* Bacteria grown on Heart Infusion agar containing $6.2 \mathrm{mcg} / \mathrm{ml}$ of CM or TC were taken as CM- and TC-resistant bacteria, respectively.

** Bacteria grown on drug free Heart Infusion agar.

$* * * \mathrm{R}^{+}$strains/strains studied. 
平均で 44.1\% とやはり高かった (Table 1)。

那賀川で採捕されたアユの腸管 $1 \mathrm{~g}$ 当りの細菌数は $2.6 \times 10^{4}$ と養殖魚の腸管の菌数に比較して少なかっだ。 また， CM 耐性菌， TC 酎性菌はともにまったく検出さ れなかった (Table 1)。

養殖池水 $1 \mathrm{~m} l$ 当りの細菌数は 1 池を除き $10^{3}$ 台であ った (Table 2)。CM おょび TC 耐性菌の出現率は池に よって異なったが，3池に拈いて TC 酎性菌が 30\%を 越えた (Table 2)。

\section{2）伝達性 R プラスミドによる耐性菌の検出}

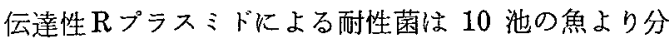
離された。伝達性 $\mathrm{R}$ プラスミドは調べた $\mathrm{CM}$ 耐性 56 株中 11 株 (19.6\%), 同しくく TC 酎性 56 株中 22 株 $(39.3 \%)$ より検出された (Table 1)。

伝達性 Rプラスミドによる耐性菌は池水中からも検出
され，調べた CM 耐性 16 株中 8 株，同じく TC 耐性 19 株中 1 株が伝達性 Rプラスミドによるるのであった。 云達性 $\mathrm{R}$ プラスミドは腸管とは逆に CM 耐性菌により 多く検出された (Table 2)。

\section{3）伝達性 R プラスミドと耐性菌の種類}

アユの腸管から薬蝺無添加培地で分離された 60 株就 よび CM 耐性および TC 酎性株各 56 株，および同様に 池水から分離されたそれぞれ 18 株，16 株抢よび 19 株 の種類を Table 3 に示した。池別の種類は示さないが， 池間で菌種の差は少なかった。本表にみられるように薬 剤無添加培地で分離された菌種と耐性菌種との間に大羑 はない。一方，ア二腸管内と池水中の菌種を比較すると Aeromonas hydrophila が前者で遙かに多く, 本種が腸 内に棲みつき易い種類であることを示している。それに 対して Vibrio anguillarum は池水からは分離されな

Table 2. Incidence of chloramphenicol- and tetracycline-resistant bacteria* in the water of Ayu (Plecoglossus altivelis) culturing ponds

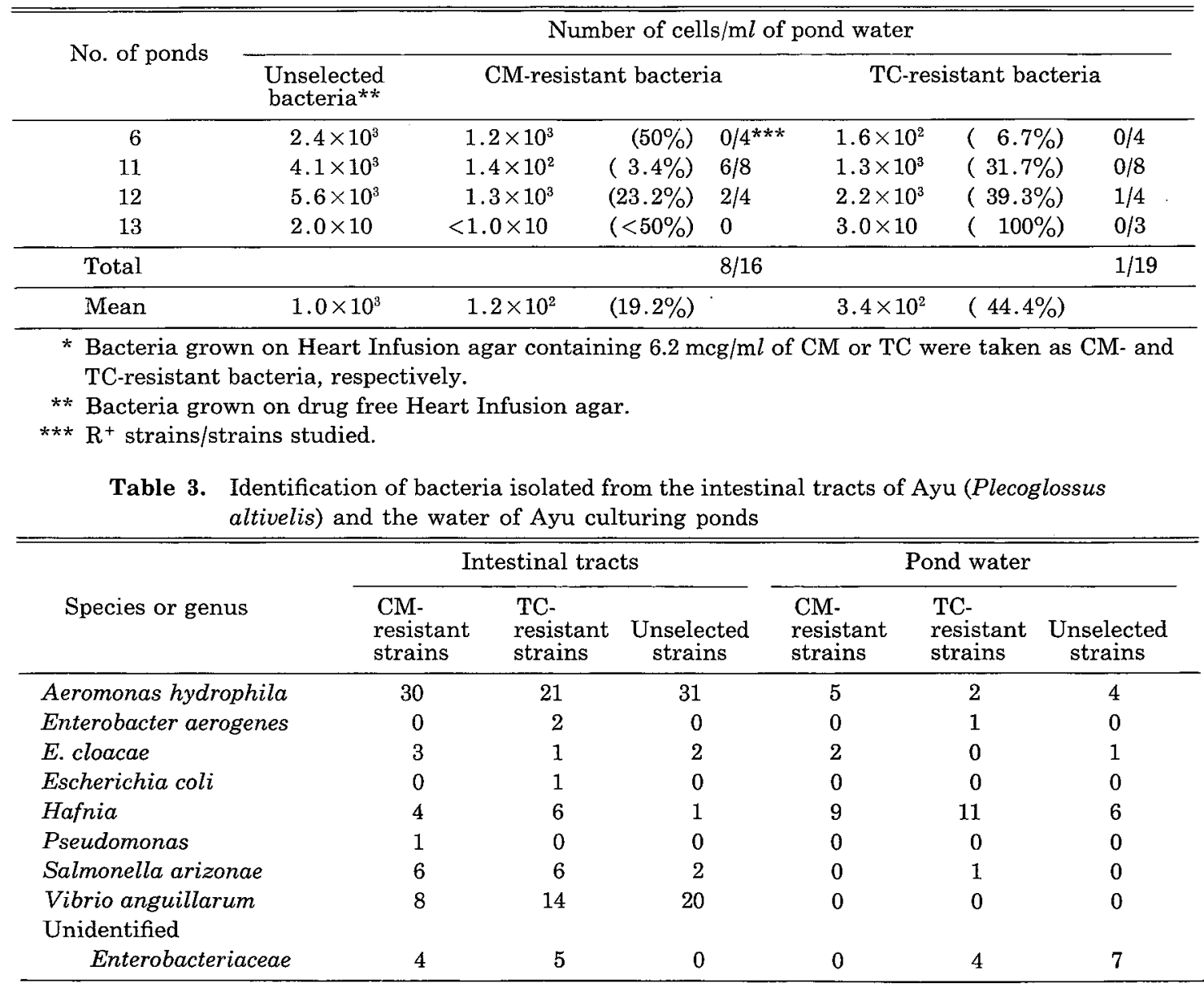


Table 4. Drug resistance markers of $\mathrm{R}$ plasmids detected in CM- and TC-resistant bacteria isolated from the intestinal tracts of Ayu (Plecoglossus altivelis)

\begin{tabular}{|c|c|c|c|c|}
\hline \multirow[b]{2}{*}{ Species or genus } & \multicolumn{2}{|c|}{ CM-resistant bacteria } & \multicolumn{2}{|c|}{ TC-resistant bacteria } \\
\hline & $\begin{array}{l}\text { No. of } \mathrm{R}^{+} \text {strains/ } \\
\text { No. of strains } \\
\text { studied }\end{array}$ & $\begin{array}{l}\text { Resistance } \\
\text { markers of } \\
\mathbf{R} \text { plasmids }\end{array}$ & $\begin{array}{l}\text { No. of } \mathrm{R}^{+} \text {strains/ } \\
\text { No. of strains } \\
\text { studied }\end{array}$ & $\begin{array}{l}\text { Resistance } \\
\text { markers of } \\
\mathrm{R} \text { plasmids }\end{array}$ \\
\hline Aeromonas hydrophila & $0 / 30$ & & $1 / 21$ & SA SM CM TC* \\
\hline Enterobacter aerogenes & & & $1 / 2$ & SA SM CM TC \\
\hline E. cloacae & $3 / 3$ & SA SM CM & $1 / 1$ & SA SM CM TC \\
\hline Escherichia coli & & & $0 / 1$ & \\
\hline Hafnia & $0 / 4$ & & $0 / 6$ & \\
\hline Pseudomonas & $0 / 1$ & & & \\
\hline Salmonella arizonae & $0 / 6$ & 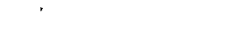 & $0 / 6$ & \\
\hline $\begin{array}{l}\text { Vibrio anguillarum } \\
\text { Unidentified }\end{array}$ & $8 / 8$ & SA SM CM TC & $14 / 14$ & SA SM CM TC \\
\hline Enterobacteriaceae & $0 / 4$ & & $2 / 5$ & SA SM CM TC \\
\hline
\end{tabular}

* Abbreviations-SA: sulfonamides; SM: streptomycin; CM: chloramphenicol; TC: tetracycline.

Table 5. Drug resistance markers of $\mathrm{R}$ plasmids detected in CM- and TC-resistant bacteria isolated from the water of cultured Ayu (Plecoglossus altivelis) ponds

\begin{tabular}{|c|c|c|c|c|}
\hline \multirow[b]{2}{*}{ Species or genus } & \multicolumn{2}{|c|}{ CM-resistant bacteria } & \multicolumn{2}{|c|}{ TC-resistant bacteria } \\
\hline & $\begin{array}{l}\text { No. of } \mathrm{R}^{+} \text {strains/ } \\
\text { No. of strains } \\
\text { studied }\end{array}$ & $\begin{array}{l}\text { Resistance } \\
\text { markers of } R \\
\text { plasmids }\end{array}$ & $\begin{array}{l}\text { No. of } \mathrm{R}^{+} \text {strains/ } \\
\text { No. of strains } \\
\text { studied }\end{array}$ & $\begin{array}{l}\text { Resistance } \\
\text { markers of } R \\
\text { plasmids }\end{array}$ \\
\hline Aeromonas hydrophila & $1 / 5$ & SA CM TC & $0 / 2$ & \\
\hline Enterobacter aerogenes & & & $0 / 1$ & \\
\hline E. cloacae & $0 / 2$ & & & \\
\hline Hafnia & $7 / 9$ & $\begin{array}{l}\text { SA SM CM (5) } \\
\text { SA SM CM TC (2) }\end{array}$ & $1 / 11$ & SA SM CM TC \\
\hline $\begin{array}{l}\text { Salmonella arizonae } \\
\text { Unidentified }\end{array}$ & & & $0 / 1$ & \\
\hline Enterobacteriaceae & & & $0 / 4$ & \\
\hline
\end{tabular}

かった。これは池水中での生存性が弱いためかと思われ る。な扔那賀川産了ユの腸内から薬剤無添加培地で分離 された 4 株はすべてV. anguillarumであった。

アニの腸管より分離された耐性菌 112 株のうち 51 株 (45.5\%) はA. hydrophilaでもっとも多く, 次いでV. anguillarum が 22 株 $(19.6 \%)$ と多かった。前者は 14 池中の 13 池から，後者は 10 池上り分離された。他に 腸内細菌群とPseudomonas が分離された。るそれに対し て池水から分離された耐性菌は Hafnia が最も多く, A. hydrophila がそれk次いだ。

V. anguillarum の CM 耐性 8 株抢よび TC 耐性 14 株はすべて伝達性 R プラスミドによるものであった (Table 4)。他に伝達性 R ブラスミドが検出されたのは Enterobacter aerogenes, E. cloacae 腸内細菌群の末同 定株，および A. hydrophila であったが, A. hydrophila
からの検出率は非常に低かった (Table 4)。

これら検出された伝達性 Rプラスミドの耐性マーカー は Table 4 に示したと㧍りであるが，E. cloacae 由米 のものを除き，全て 4 片耐性であった。

池水上り分離された $\mathrm{CM}$ 耐性菌拉よび $\mathrm{TC}$ 耐性菌の らち Hafnia 怙よび A. hydrophila からのみ伝達性 R プラスミドが検出された。その耐性マーカーは Table 5 に示したと拈りである。

\section{考察}

今回調査を行なった徳島県下の養殖場のアニの腸管内 の $\mathrm{CM}$ 耐性菌㥂よび $\mathrm{TC}$ 耐性菌の出現率は非常に高か った。すでに著者らが報告した他の養殖魚（コイ，ウナ ギ, ニジマス，アマゴ,ヤマメおよびブリ）の腸管の CM 耐性菌拉上び TC 耐性菌出現率 (AoKI et al., 1977) 
よりも遙かに高い値を示した。さきに著者 (AOKI, 1975) はフユ養殖場における化学療法剤の使用頻度と, アニの 腸管内の CM 耐性菌および TC 耐性菌の出現率を比較 し，化学潦法凧の使用頻度の高い養殖場ほどこれら薬剤 耐性菌の出現率が高いことを示唆した。今回も調查した 養殖地のほとんどすべてで多種多様の化学療法剤が使用 されていた。一方，河川で採捕された化学療法剤に触れ ていないと思われるアニの腸管から耐性菌は検出されな かった (Table 1)。これらの事実より，養殖場で薬荗が 使用されることによりアユの腸管内で耐性菌が選択さ れ，増加したものと思われる。

また，盖殖池水中の耐性菌出現率も，腸管における耐 性菌出現率に比べれば低かったが，やはり高い値を示し た (Table 2)。さらに, 他の養殖魚種の養殖池水中の CM 耐性菌および TC 耐性菌出現率 (AoKI et al., 1977) よりも高かった。

荃殖アユの腸管から分離された細菌の種類としては A. hydrophila がもっとも多く, 次いでV. anguillarum であった (Table 3)。その他は Pseudomonas おょび腸 内細菌群であった。特に, A. hydrophila は 14 池中の 13 池の魚から検出された CM 耐性菌, TC 耐性菌とも この 2 種が多かった。しかし A. hydrophila 耐性株は伝 達性 $\mathbf{R}$ プラスミドによるすのは極めて少なかった (Table 4)。一方，コイ（青木，1973）およびウナギ（青 木ら，1973；AOKI et al., 1971）から分離された A.

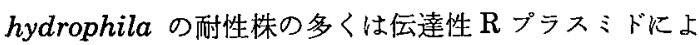
るものであった。A. hydrophila はこれら魚種のよく知 られた病原菌であるが，アコに対する病原性はあまり強 いものとは思われない。しかしRプラスミド耐性菌の出 現をこの点に結びつけて考えることは適当とは思われな い。この問題は今後の研究課題としたい。

V. anguillarum の耐性株は 14 の養殖池のちちの 10 池の魚より分離された。各養殖池から分離された 22 株 のすべてから 4 剂耐性 SA, SM, CM, TC の伝達性 R プ ラスミドが検出された (Table 4)。このことは養殖場に おいてV. anguillarum の耐性菌感染症が起こっている ことを示唆しているものと思われる。 $V$. anguillarum がアユ養殖場へ導入されるルートは明らかではない。し かし，その耐性菌から検出された伝達性 Rプラスミドの 性状がすべて一致したこと（AOKI et al., 1975),さらに， 多くの養殖場から分離された菌株の血清型が一致するこ と（青木ら，1978）から，V. anguillarum 耐性株はア ユの移動とともに養殖場へ導入された可能性が充分に考 えられる。今後, この点を考虑した防疫体制の確立が望
まれる。

\section{要 旨}

1974 年 4 月, 徳島県下の 14 の養殖場のアニの腸管お よび池水中の chloramphenicol (CM) 耐性菌および tetracycline (TC) 耐性菌を定量的に分離した。那賀川 で採捕された野生アニの腸管についても同様に行なっ た。その結果着殖アユの腸管あるいは池水より $\mathrm{CM}$ 耐 性菌おょび TC 耐性菌が高頻度に検出された。一方，野 生アユからはまったく耐性菌は検出されなかった。分離 耐性菌種は Aeromonas hydrophila がもっとも多く, 次いでVibrio anguillarumであった。他に腸内細菌群 および Pseudomonas であった。伝達性 R プラスミド はV. anguillarum の耐性株加らっとも多く検出さ れ，腸内細菌群扎よび A. hydrophila 耐性株の一部か

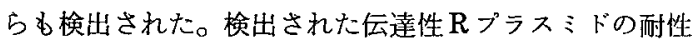
マーカーの汪とんどは sulfonamides, streptomycin, $\mathrm{CM}, \mathrm{TC}$ の 4 剂耐性であった。

\section{謝 辞}

調查の際にご援助をいただいた徳島県水産試験場元場 長小竹子之助氏，同試験場田原恒夫氏，元同試験場研修 生故芦田穆氏に深く感謝の意を表する。

なお，本研究の一部は文部省科学研究費補助金によっ て行なわれた。

\section{文献}

青木 宙 (1973): コイの養殖池水および腸管より分 離された薬剂耐性菌の研究. 日水誌，40,247-254.

AOKI, T. (1975): Effects of chemotherapeutics on bacterial ecology in the water of ponds and the intestinal tracts of cultured fish. Ayu (Plecoglossus altivelis). Japan. J. Microbiol., 19, 712.

Aoki, T., T. AraI and S. Egusa (1975): R factors detected from Vibrio anguillarum and marine Vibrio. Microbial Drug Resistance. pp. 223228. Edit. by S. Mitsuhashi and H. Hashimoto. University of Tokyo Press, Tokyo.

Aoki, T., S. Egusa and T. AraI (1974): Detection of $\mathrm{R}$ factors in naturally occurring Vibrio anguillarum strains. Antimicrob. Ag. Chemother., 6, 534-538.

青木 宙・北尾忠利 (1978)：アユのビブリオ病。魚 病研究, 13, 19-24.

Aoki, T., T. Kitao, and T. Arai (1977): R plasmids in fish pathogens. Plasmids Medical and Theoretical Aspects. pp. 39-45. Edit. by S. 
Mitsuhashi et al. Avicenum, Czeckoslovak Medical Press, Prague.

Aoki, T., S. Egusa, Y. Ogata and T. Watanabe (1971): Detection of resistance factors in fish pathogens Aeromonas liquefaciens. J. Gen. Microbiol., 65, 343-349.

青水雷・渡辺力 (1973): ウナギの養殖池水抢上 び腸管より分崔された薬剤菂性菌の研究. 日水誌,
39, 121-130.

Buchanan, R. E. et al. Editors (1974): Bergey's Manual of Determinative Bacteriology 8th Edn., Williams and Wilkins Co., Baltimore.

Cowan, S. T. (1974): Cowan and Steel's Manual for the Identification of Medical Bacteria 2nd Edn., Cambridge Univ. Press, London. 